\title{
How Democracy Promotion Became a Key Aim of Sweden's Development Aid Policy
}

\author{
JOHAN KARLSSON SCHAFFER
}

\subsection{Introduction $^{1}$}

Why has Sweden come to occupy a special role as a promoter of democracy through official development assistance (ODA)? Among donor countries, Sweden stands out not just because of the state's comparatively high levels of ODA, but also because a comparatively large proportion of the ODA budget is channeled into promoting democracy, human rights, and civil society (Crawford 2001; Youngs 2008). Since the end of the Cold War, the previously merely nominal official policy goal of fostering democratic development has become a key cornerstone of Swedish ODA, broadly shared by political parties and other stakeholders. Policymakers also frequently claim that Sweden - owing to its own historical experiences of creating stable, peaceful forms of popular government - has a special mission to promote democracy, good governance, and human rights in countries less fortunate - a national brand of sorts.

Seeking to explain the seemingly exceptional role Sweden - often seen as an exemplar of the so-called Nordic model - has played in international politics in the post-World War II era, a line of existing research suggests that Nordic foreign policy exceptionalism results from distinct values of solidarity, (social) democracy, and equality prevalent in domestic society (e.g. Lawler 2005; Bergman 2007; Rosamond 2015; Witoszek and Midttun 2018). The internationalist orientation of Sweden and the other Nordic states comes to the fore not least in their comparatively generous development aid policies. The Nordic states occupy this

${ }^{1}$ I am very grateful to the editors Antoine de Bengy Puyvallée and Kristian Bjørkdahl for putting together this volume and for their generous and constructive comments on several earlier think pieces and drafts of this chapter. I also wish to thank Helena Lindholm and Erik Jennische for their insightful comments on a previous version. 
exceptional role, this line of literature suggests, because they extend the egalitarian and solidarist values, upon which their domestic political and social institutions are based, to distant others, in a truly cosmopolitan fashion. Consequently, this view would locate the source of Sweden's seemingly extraordinary efforts to promote democracy and human rights in values of democracy, popular participation, and human rights deeply engrained in domestic culture.

However, such culturalist accounts of foreign policy exceptionalisms come with a number of analytical limitations. They tend to mystify rather than clarify the influence of values and beliefs on international outcomes and fail to specify the causal mechanisms through which domestic values get translated into foreign policy commitments. They also tend to reify certain interpretations of domestic values, thus neglecting that foreign policy, including development assistance and human rights commitments, is produced through contentious political processes where political elites mobilize different values and beliefs in their competition for dominance. And since societal values change only slowly, culturalist accounts have difficulties explaining variation in the shorter term. In brief, domestic culture is too blunt a tool to analyze the changing aims and strategies governing development aid policy.

In this paper, I seek to provide a different account of Swedish foreign policy exceptionalism, using democracy promotion through ODA as an illustrative case. For some time now, Sweden has sought to promote democracy through its development aid policy. While policy documents point to historical experiences and predominant conceptions of democracy in Sweden to justify policy, I shall argue that the beliefs governing Swedish democracy promotion efforts are not engrained in a primordial national culture, but rather produced through political processes that involve contestation and sometimes result in compromise, sometimes in conflict. The outcomes of such processes are also shaped to a large extent by international factors, including major geopolitical events and economic conjectures, changing international norms, and evolving global governance institutions. Empirically, the paper analyzes how policymakers have framed the aims and strategies of democracy promotion in development assistance from the 1960s to the 2010s. By moving beyond culturalist accounts, the paper thus both provides a better understanding of Swedish internationalism and a different empirical account of democracy promotion efforts in Swedish ODA.

This chapter is structured in four parts. First, I briefly seek to pinpoint how Sweden's democracy assistance compares internationally. Next, 
I critically engage with culturalist accounts of Nordic foreign policy exceptionalism and present an alternative account which suggests that government policy results from domestic political processes that are partly shaped by international opportunities and constraints. Then, I analyze the emergence and evolution of democracy assistance in Swedish ODA through three episodes: (i) the first decades' relativist indifference toward democracy; (ii) the breakthrough of democracy and human rights promotion with the end of the Cold War; and (iii) its contested ascendance in the new millennium. Finally, in the concluding section, I reflect on the broader usefulness of this explanatory approach and on the shifts in policy that it helps us capture.

\subsection{Sweden: An Outlier in Democracy Promotion through Development Aid}

In some vital respects, Sweden's development aid policy is and has long been exceptional, by international comparison. Sweden is the largest donor in terms of net ODA in proportion to gross national income (GNI), and the seventh largest donor in absolute terms. In 1975, Sweden was the first country to meet the United Nations' target of allocating 0.7 percent of gross national product to ODA and has continued to meet it ever since. Sweden thus belongs in a small club of countries that have ever met the target, and one of only five (alongside Norway, Luxembourg, Denmark, and the Netherlands) to have reached or exceeded it consistently. Sweden has further set a national commitment to spend 1 percent of GNI on ODA (Ekengren and Götz 2013). Hence, in quantitative terms, both relative and absolute, Swedish ODA is uniquely generous.

High levels of ODA have been described as a traditional characteristic of the so-called Nordic aid model. Beyond its munificent signature, Nordic aid has also been characterized by giving aid mainly in the form of grants rather than loans; focusing on the least developed countries, with the bulk of aid channeled to Sub-Saharan Africa; being oriented toward poverty reduction, social infrastructure, and welfare; strong support for multilateralism, especially the United Nations' development aid regime; and an emphasis, at least nominally, on recipient ownership (Elgström and Delputte 2016: 31; cf. Kärre and Svensson 1989). While Nordic aid policy objectives and instruments have changed since the mid-1990s, for instance by an increasing ratio of bilateral to multilateral aid (Laakso 2002: 57), its basic structure and implementation on the 


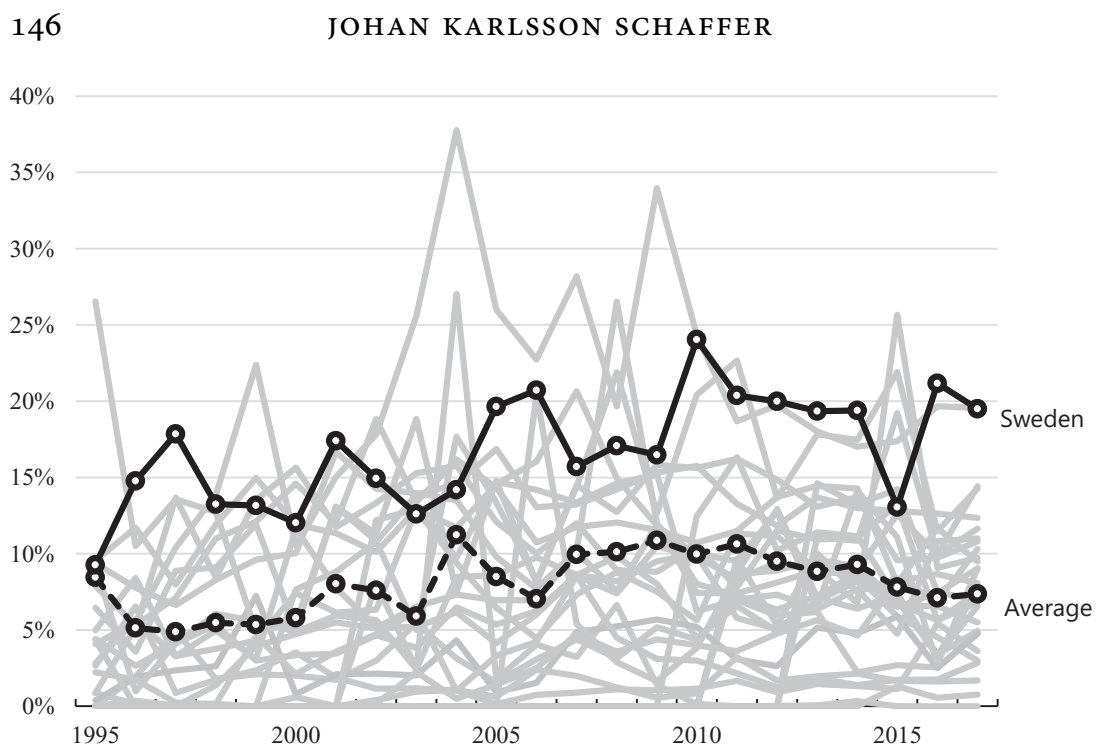

Figure 7.1 Proportion of ODA allocated to government and civil society, 1995-2017. Source: OECD DAC Creditor Reporting System.

ground shows considerable consistency over time (Elgström and Delputte 2016: 34). Another distinctive trait of the Nordic model is that the states have long sought to coordinate their foreign aid policies and collaborate on joint development projects, to achieve greater impact with limited resources (Laakso 2002: 56f).

While all the Nordic states have come to emphasize support for democracy and human rights in their overall development cooperation policies since the 1980s, Sweden has stood out by international comparison in terms of its expenditures for democracy, good governance, and human rights promotion (Figure 7.1). In recent decades, democracy, human rights, and good governance have come to occupy an increasingly central role and development aid targeted at government and civil society has become a major sector of Swedish ODA. In the period 1995-2017, it amounted on average to 16.8 percent of the total ODA budget - twice the Organisation for Economic Co-operation and Development (OECD) donor average of 8 percent. Democratic governance and human rights has been the best-funded sector of Swedish development assistance (Youngs 2008).

Swedish political aid also has some peculiar features that set it apart from other donors that emphasize democracy in their ODA. In the 


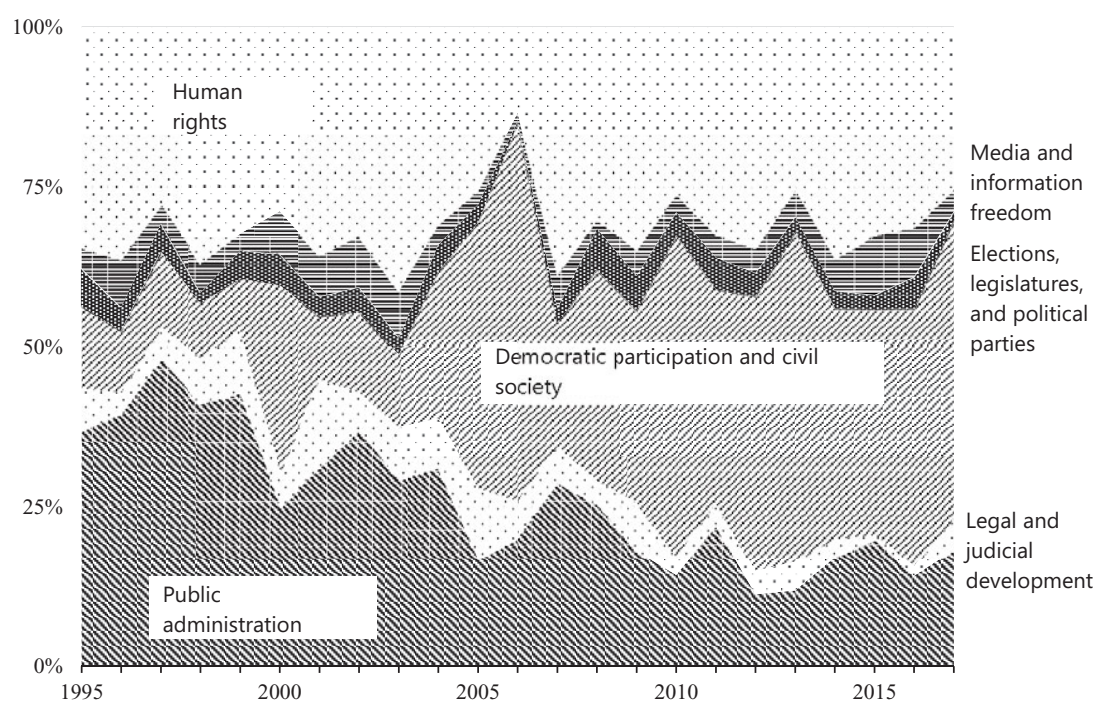

Figure 7.2 Swedish "government and civil society" ODA by subsector, 1995-2017. Source: OECD DAC Creditor Reporting System. "Public administration" includes "Public sector policy and administrative management," "Public finance management," "Decentralisation and support to subnational government," "Domestic revenue management," and "Anti-corruption organisations and institutions." "Human rights" includes also "Women's equality organisations and institutions" and "Ending violence against women and girls."

expansion phase in the 1990s, Sweden's democracy promotion efforts were more focused, compared to other donors, on promoting a democratic civil society and less on strengthening democratic government institutions (Crawford 2000, 2001). A distinctive characteristic is the focus on "democratic participation and civil society," and "human rights," respectively (Figure 7.2) - subsectors that each have amounted to on average 28 percent of Swedish development aid in the "government and civil society" sector. By contrast, smaller proportions are allocated to democratic and rule-oflaw institutions such as legal and judicial development, elections, and legislatures and political parties. In the "government and civil society sector," Swedish development aid has also devoted a considerable but declining percentage to supporting public administration reform, reflecting beliefs that state capacity building, good governance, and public sector efficiency and transparency are instrumental to democratization.

While these figures reveal that Sweden is somewhat of an outlier in development assistance generally and democracy promotion 
specifically, they say little about Sweden's motivations for engaging in development cooperation and democracy promotion, about the overarching aims and specific strategies Sweden pursues, and whether its efforts are effective in reaching the stated aims of democratic development. For instance, while the support Sweden has given to elections, legislatures, and judicial institutions is small compared to support for civil society and human rights, it might well be the case that some low-cost or small-scale interventions are more indicative of donor commitment and/or have more significant impact on recipient state democratization than more costly or extensive types of support. Furthermore, figures of ODA flows say little about how development aid and democracy promotion fit into the bigger picture of Sweden's foreign policies, such as security, trade and investment, or multilateral cooperation within Nordic, European, and global governance institutions. What the figures do reveal, though, is an interesting puzzle to explain: Why does Sweden stand out, in international comparison, and even relative to its equally high-donating Nordic neighbors? The next section will turn to competing explanations for this seeming exceptionalism in Swedish development aid.

\subsection{Culturalist Accounts of Nordic Foreign Policy Exceptionalism}

In foreign policy and international relations research, Sweden - an exemplar even among the internationalist Nordic states - has been described as a "moral superpower" (Dahl 2005), an "agent of a world common good" (Bergman 2007), a "global good Samaritan" (Brysk 2009), or simply a "good state" (Lawler 2005). The flattering epithets seek to capture the peculiar role Sweden - which this literature often treats as the quintessentially Nordic state, so I will assume culturalist accounts of general Nordic exceptionalism are also representative of Sweden - has played in world politics over the past half-century, as expressed, e.g., in support for decolonization, third-world national liberation movements, and the struggle against apartheid in southern Africa; mediation and peacekeeping efforts in international crises and conflicts; comparatively high levels of foreign development aid; a high profile in multilateral organizations, especially the United Nations; and generous reception of refugees. Thus, this literature suggests that Sweden and the other Nordic states have a standing in world affairs that is not warranted by their minor size and conventional power but rather grounded in a particular form of internationalist orientation, the cornerstone of which 
is a strong commitment to humanitarianism and human rights globally, that has guided Nordic foreign policies. ${ }^{2}$

Seeking to account for Sweden's and its neighbors' seemingly exceptional role in world affairs, existing literature chiefly locates the causal factors to values and ideas dominant in domestic society. For instance, Annika Bergman Rosamond (Bergman Rosamond 2007; cf. Bergman Rosamond 2015) argues that the particular brand of internationalism that characterizes Sweden's foreign policy is based on a "thin conception of cosmopolitan duty that does not exclusively privilege the rights of Swedish nationals alone, but recognizes the need to extend social and political rights to non-nationals as well." On Bergman Rosamond's view, this cosmopolitan foreign policy orientation is a product of a domestic welfare state regime based on the values of solidarity, inclusiveness, and universality, as foreign policy and domestic policy are co-constitutive. Alison Brysk (2009) claims that Sweden has come to reconstruct its national interest as humanitarian internationalism through a continuous dialogue between domestic values and ideology, and international society. Similarly, Peter Lawler (1997) argues that a Nordic public discourse, which emphasizes the value of solidarity, "has not only become socially embedded because of domestic legislation, but also because of the regional and foreign policies of the Scandinavian states." This Nordic exceptionalism is not just a pragmatic foreign policy of a set of minor states on the fringe of Europe, but "it is also driven by their distinctive domestic values, including that of solidarity" (Lawler 1997: 568). Looking at development aid specifically, Susan Holmberg concurs that "foreign aid, in effect, became an extension of Sweden's domestic welfare policy" (Holmberg 1989: 126), allegedly based on primary values such as humanitarianism, solidarity, equality, and justice. Adopting a longer historical frame, Mikko Kuisma (2007) suggests that the internationalist orientation of the Nordic states rests on a normative legacy that actually predates the modern nation state. Thus, from various theoretical perspectives, existing literature indicates that the Nordic states' presumed exceptional role in world affairs has been shaped by values, norms, and ideas prevalent in Nordic societies.

While locating the roots of foreign policy exceptionalism in domestic culture provides a seemingly coherent explanation, it comes with a number of inherent limitations (Langford and Schaffer 2015): First, given

2 This section partly draws on arguments I've developed in previous works (Schaffer 2017, 2020; Langford and Schaffer 2015). 
the complex system of a multitude of ideas and values that comprise a national culture, it becomes difficult to assess their relative importance in explaining foreign policy behavior. Second, explanations in terms of culture sometimes seem to mystify more than they clarify, or provide only superficial accounts of the domestic values that supposedly determine policy. For instance, research on Nordic welfare state regimes suggests that beyond rhetoric, their moral logic is not based on altruistic solidarity among citizens, but on conditional reciprocity (Rothstein 1998): Citizens accept to pay their high taxes knowing that others do too and that they get most of it in return as public services. Third, many culturalist accounts fail to specify the mechanisms by which values shape policy - at best, the causal link is implied. For values to influence policy, purposive agents need to mobilize ideas for policy purposes. Specifically, failing to specify the agents that mobilize ideas obscures how dominant discourses are the products of processes of political contestation (V. A. Schmidt 2008). Furthermore, prioritizing values and ideology in domestic society risks underplaying how international factors - both material and ideational - have shaped the Nordic states external engagements, through e.g. agenda-setting, diffusion of international norms, or simply by imposing geopolitical constraints on the choices foreign policy elites make. Finally, the culturalist approach has difficulties explaining change and variation over time or across issue areas, since historically rooted cultural values largely remain constant or change only over the long haul. In sum, the culturalist approach offers incomplete tools for unpacking the exceptional international behavior of Sweden and the other Nordic states.

Instead of theorizing Sweden's supposed development aid policy exceptionalism as an extrapolation of values predominant in domestic culture, I believe it is more fruitful to assume that development aid policy is made and remade pretty much like any other area of public policy that is, through processes where various political elites pursue their aims, constrained by power resources, institutional frameworks, interactions with other players, and dominant beliefs. Since political elites have partly diverging aims and represent potentially conflicting interests, such processes are often contentious, but whether they result in conflictual disagreement, compromise bargains, or a consensus acceptable to most players may vary, depending on the various constraints, such as the line-up of actors, their relative power, their ideological preferences, and the patterns of their interactions. In foreign policy matters, there is often 
a strong pressure toward consensus, in the sense of getting all key players to toe the line on key "high politics" issues of international security or trade, but the "low politics" of development aid policy may be an area that at times offers greater room for politicization.

In an externally oriented policy area such as development aid, policy processes are also shaped by international influences, ranging from the hard realities of geopolitics to the soft power of international norms. For instance, governments may be more likely to engage in promoting democracy and human rights abroad if they perceive the international context as less hostile, while strategic interests may prevail in a more threatening environment (Huber 2015). In the period I study here, the terms for pursuing a development policy have been altered fundamentally by events and processes such as the Cold War and its end, decolonization, recurrent financial crises and economic transformations, and the third wave of democratization. Moreover, international norms have also shifted, most importantly with the breakthrough in the late 1970s of human rights and democracy as principles guiding Western foreign policy objectives, which have arguably waned since the turn of the millennium.

Furthermore, development aid policymaking is also shaped by strategic interaction with other agents, ranging from the multilateral organizations seeking to coordinate and harmonize national ODA policies to competition with other donor states, pursuing their own set of political, diplomatic, and commercial aims through development aid policy. Hence, development aid policy is not made only from the inside out, but also by the constraints and opportunities set by world politics. While my theoretical ambitions in this chapter are modest, the approach I take seems loosely compatible with a range of approaches to international relations theory that emphasize the interaction between domestic and international politics.

Within this explanatory model, ideational factors play a causal role more specific than on the culturalist approaches. Political actors mobilize ideas for their purposes, and, if they are successful, embed them as governing norms in societal institutions. Once institutionalized, those norms can also influence how actors behave, for instance by restructuring the incentives and disincentives decision makers face down the road (Berman 2013: 230). In this chapter, I discuss how certain ideas about the normative values that ought to govern Swedish foreign aid for democracy promotion were inscribed in policy documents. Obviously, 
these ideas are not traditions ingrained in a primordial Nordic culture, but rather norms - i.e., "collectively held belief[s] that [govern] thought and behavior in some specific and circumscribed area of political life" (Berman 2013: 224) - which agents have embedded in state institutions at a certain point in time. Thus, by defining ideational factors more narrowly, as purposive beliefs, delimited in time and space, and associated with specific actors, they become more useful for explanatory analysis than the amorphous notions of national culture or mentality.

In the following section, I will analyze the evolution of democracy promotion in Swedish ODA policy, from the inauguration of large-scale, state-led ODA in the 1960s to the present day. The analysis is divided into three historical episodes: In the 1960s-1970s, democratization was only a nominal aim of ODA policy and the coming to power of a nonsocialist government in 1976 entailed no major shift in priorities. In the 1980s1990s, the Conservative party mobilized for greater emphasis on democracy and human rights in ODA, which became a key priority from 1990. Finally, in the 2000s-2010s, democracy promotion became the single largest sector of SIDA administered aid.

\subsection{Promoting Democratization in the Very Long Term}

While government-funded development aid has a longer history in Sweden, the founding moment of Sweden's official development assistance is a public inquiry commission, appointed in 1961. It included heavy-weight members such as prime minister Tage Erlander, minister of finance Gunnar Sträng, and, as secretary of a sub-commission, Olof Palme (then head of division in the Cabinet Office), as well as representatives of a broad set of interest organizations and civil society groups. The commission's report (Utrikesdepartementet 1962a) resulted in a government bill (Utrikesdepartementet 1962b) which for a long time served as a foundational document, often referred to as "the Bible of Swedish development aid," setting the aims and fundamental principles, guidelines and strategies, and the long-term structure for foreign aid (Hook 1995: 98; Wohlgemuth 2012: 5). While aid to developing countries had previously chiefly been administered by civil society organizations, government now also created a new national agency, with considerable independence from the foreign ministry, to coordinate Swedish development assistance, which with its expansion in 1965 was renamed as the Swedish International Development Authority (SIDA). 
Set in a context of Cold War rivalry and an accelerating process of decolonization, the 1962 bill aimed for Sweden to pursue a development aid policy untainted by the self-serving political motives it ascribed to other industrialized states. Among the key guiding principles, Sweden should concentrate aid on a small number of recipient countries and a limited range of activities; moreover, to secure the independence of aid vis-à-vis other domestic and foreign policy objectives, it should not be tied to procurement in Sweden (Brodin 2000: 28). The emerging developing policies were also part of a broader foreign policy orientation attributing to Sweden a special bond to the third world: because of its tradition of social reformism and democratic socialism, Sweden was especially well placed to understand the developing countries' demand for change (Lödén 1999: 192f).

The overarching objective of Swedish ODA set by the 1962 bill was to "raise the standards of living of the poor peoples" (Utrikesdepartementet 1962b: 7) - by targeting famine, mass poverty, epidemics, and infant mortality, and generally creating conditions for a decent life. A key operational goal to reach the overarching objective was to contribute to an increase in production that outpaces population growth. The bill also stressed political democracy as one of the key aims justifying Swedish ODA and its preamble approvingly cited recently perished UN Secretary General Dag Hammarskjöld's interpretation of the UN Charter as based on "the fundamental democratic principle of equal political rights [and also] a right to equal economic opportunities." Swedish ODA would also "contribute, as far as assessable, to a societal development in a politically democratic and socially equalizing direction" (Utrikesdepartementet 1962b: 3). However, the bill ruled out political conditionalities and cautioned against imposing Western models of society on developing countries, as "it is not evident that the social and political system and principles to which we adhere are fit for purpose or achievable for all developing countries" (Utrikesdepartementet 1962b: 7). As foreign minister Torsten Nilsson clarified the primacy of poverty reduction over democracy and human rights, "first, the fundamental needs of human beings must be satisfied; then, one can begin demanding of them the kind of democratic responsibility and respect for the individual person's rights and liberties that has emerged in the more developed and stable societies in the West" (Lödén 1999: 146). To provide long-term planning for the expanding development aid sector, a 1968 government bill elaborated on the operational goal to further the economic independence of newly 
decolonized states, as a precondition for "democratic societal development and real national independence" (Utrikesdepartementet 1968).

Thus, while Swedish ODA policy included democratization as an aim already in the 1960s, it was, in principle and practice, eclipsed by the aim of raising the standards of living of "poor peoples." The key objective was to contribute to social and economic equalization - both within the recipient states and, by fostering their economic independence, between them and the industrialized states. The government's policy regarded development and equalization as instrumental prerequisites for national independence and, in the long run, democratic development. As a result, the policies included no concrete strategies or instruments for furthering democratization.

Already in the 1970s, however, some of the key principles of Swedish aid would be compromised and stir controversy. In 1970, government launched the country-programming system, setting principles for the selection of recipient countries: Sweden should seek cooperation with countries whose governments pursued redistributive policies and that had a potential for democratic and economic development, yet also focus on poor, underdeveloped countries. The nonsocialist parties criticized the selection principle, disputing the politicization of aid that would follow if Sweden, like the great powers, allowed homegrown values to determine the choice of recipients rather than the needs in the target countries. Maintaining the needs principle, Conservatives proposed terminating aid to Cuba on the grounds that its GDP exceeded that of most other recipients and argued that selecting countries demonstrating a will to social and economic equalization had led government to prioritize socialist regimes (Brodin 1992: 31f, 2000: 29). The Communists, by contrast, endorsed selecting countries on the basis of their aspirations for economic and social equality, but argued that government failed to apply the principle consistently.

In 1972, the government appointed another parliamentary commission (BPU, Biståndspolitiska utredningen) to propose more detailed guidelines for development aid. In part, policy revision was necessitated by the expansion of Swedish development assistance, but also by the economic crisis of the 1970s which had inclined policymakers to make future ODA transfers more in line with domestic economic interests (Hook 1995: 101). For instance, finance minister Sträng conditioned expanded ODA to reach the 1 percent goal by 1975 on increased procurement in Sweden (Odén 2017).

When the BPU commission delivered its final report in 1977, the nonsocialist parties had formed government for the first time in more 
than 40 years. While the cross-partisan commitment to expansive development aid remained, the new government sought to increase the domestic economic interest component and sought to shift the focus of ODA, from local ownership to more active donor involvement and stricter terms on the recipients, from capital-intensive investments to smaller-scale interventions, and from multilateral to bilateral aid (Hook 1995: 101). Furthermore, while the government largely maintained country programming, it reduced aid to e.g. Cuba (Crawford 2001: n. 25) due to its destabilizing military interventions in Africa, and also demanded more efficiency, evaluation, and accountability in the development aid sector (Brodin 1992: 49). While the Conservatives had long favored reducing the volume of aid, the development aid portfolio was controlled by the expansionist Liberal party in all successive nonsocialist governments between 1976 and 1982 .

The BPU report and the resulting bill provided a new systematization of the goals laid down for Swedish development assistance in the 1960s. The report proposed specifying democratic development as an operational goal, yet raised several caveats against imposing a supposedly Western model of democracy on developing countries, called for a tolerant conception of democracy, and reiterated the need for a longterm perspective:

[T] the economic situation often makes it difficult to bring about a democracy that is working in a Western sense. In its practical application, the democratic societal system in the Nordic countries builds not only upon the principled preconditions of free and secret elections, freedom of association and independent mass media. Important are also the economic preconditions - general literacy, an income distribution that begets economically strong organizations for different interest communities, participation in the decision-making process outside of the political field, and a tradition that reduces the ever-present threat against open societal systems. Against this backdrop, it is natural to connect the hopes of a democratic societal form to development in the long run and a relatively wide interpretation of the concept of democracy. (Utrikesdepartementet 1977: 234)

Thus, the commission argued, one shouldn't restrict one's view to the formal framework of democracy as understood in the West: Single-party systems could offer opportunities for broad popular participation in decision-making processes, to the extent that they allow for critical debate without fear of repression, and lay a foundation for further developing a democratic social order (Utrikesdepartementet 1977: 40). 
The commission devoted only one single page out of more than 400 to the goal of democratic development, indicating its low priority (Crawford 2001: 56).

The commission's circumspect attitude to democratization was reflected in the resulting bill that Ola Ullsten, minister for development aid, presented to parliament the following year. The bill expressed hopes that economic development in the long run would lead to democratic development, but also cautioned that developing countries often lack the social and economic and, implicitly, cultural preconditions for maintaining democracy. For instance, "the majority of developing countries lack the political tradition and value community that made democracy the self-evident form of government in e.g. the Nordic countries. Thus, it is necessary to tie the hopes of fully democratic form of society to development in the longer run" (Utrikesdepartementet 1978). In line with the rise of human rights on the agendas of world politics from the mid1970s, the bill also gave human rights a more central place in Swedish development aid policy, as a value more fundamental than democracy, yet did not elevate promotion of human rights to an official goal of Swedish ODA.

To sum up, although democratic development was explicitly stated as an aim for Swedish ODA policy from the start, it was demoted to irrelevance in principle and practice. Seeking to relate the aims laid down in the 1962 bill to one another, the BPU presented economic and social equality as the principal aims, for which growth, equalization, and democracy were instrumental. The 1978 bill instead specified the four aims as equally important, yet emphasized economic growth, and considered democratic reform - in a sense so wide it could include single-party rule - a goal for the longer term. As a result, throughout the 1970s democracy promotion largely remained a nonissue, and while Conservatives had charged the government with prioritizing socialist regimes and condoning their lack of democracy (Boréus 1994: 215; Brodin 2000: 29), the government shifts in 1976 and 1982 caused no dramatic changes in Sweden's preference for socialist recipient countries (Kärre and Svensson 1989). On the dominant view, Sweden should support developing countries without interfering in their domestic political systems. For instance, in Swedish development cooperation with Vietnam in the 1970s, policy documents did not draw on Sweden's experiences of democratization and avoided questioning the democratic legitimacy of the Communist regime (Brodin 2000: $38 \mathrm{n} 1$ ), and politicians criticizing the Bai Bang paper mill - the single 
most expensive Swedish development aid project ever, with a final tab 260 percent over budget - chiefly framed their critique in technical terms (Bjereld and Demker 1995: 285ff). Similarly, Conservatives arguing for terminating aid to Cuba chiefly pointed to its comparatively high GDP and its destabilizing interventions in Africa, rather than to its autocratic regime. Political considerations were more decisive, however, in the case of authoritarian rightwing regimes: Sweden provided socalled humanitarian assistance to liberation movements in Southern Africa and to victims of political oppression under military dictatorships in Latin America (Crawford 2001: n24; Laakso 2002), and terminated a development cooperation agreement with Chile after the coup in 1973 (Axell 1989).

\subsection{The Breakthrough of Democracy and Human Rights Promotion}

In the 1980s, the previous decade's hopes for a "new international economic order" were crushed by the escalating Third World debt crisis. International financial institutions gained a new prominence in development with their focus on macro-economic reform and structural adjustment programs, and Western development policies increasingly turned from a focus on the state to civil society and the market. The Carter administration had spearheaded democracy and human rights as foreign policy objectives, and the United States began engaging in democracy promotion more consistently by the mid-1980s, while the European Community followed suit only toward the end of the decade (Huber 2015). The previously popular belief that authoritarian regimes might be better equipped than democratic governments to lead economic development was falsified by widespread corruption and kleptocracy, and the international institutions increasingly associated development aid with good governance (Mikaelsson 2008: 174). With the so-called third wave of democratization, numerous countries in Latin America, Asia Pacific, and Sub-Saharan Africa transitioned to democracy, while the end of the Cold War and the dissolution of the Soviet Union implied a major geopolitical shift with global consequences for both donor and recipient countries.

This changing international landscape provided opportunities for forces that sought to reform Swedish development aid policies. Having thus far hardly prioritized the issue, the Conservatives now increasingly began challenging the cross-partisan consensus on development aid, 
arguing that aid should not be exempted from the budget cuts necessitated by the economic downturn, that commercialization and tying of aid should be encouraged, and that the selection of recipient countries should be balanced toward nonsocialist regimes (Kärre and Svensson 1989: 233, 252). Increasingly emphasizing freedom, democracy, and human rights as foreign policy objectives (Bjereld and Demker 1995: 145), the Conservatives also pointed to violations of human rights in recipient countries and demanded a strategy for democratic reform (Brodin 2000: 32). Moreover, while the Liberal and Centre parties only marginally diverged from the government's recipient selection policy and criticized Conservatives for abandoning the needs principle, they successively sided with the Conservatives in increasingly disputing the countryprogramming system, demanding more influence and control for SIDA (Kärre and Svensson 1989: 233, 252; Brodin 1992: 58f). The Social Democrats, with a strong support base among industry trade unions, were susceptible to demands for laxing the 1 percent target and increasing return flows, but often met pushback against reform proposals from the other parties and internal opposition.

Back in government after the 1982 elections, the Social Democrats resisted the opposition's demands for terminating ODA transfers in case of human rights violations and their first bill on development aid failed to mention the democracy promotion aim (Brodin 1992: 68). According to official doctrine, humanitarian needs would guide Swedish ODA. As democracy promotion began dominating aid discussions from the mid1980s, government successively gave it a more prominent role, but insisted on regarding democratization as a long-term goal and "direction of movement," and promoting democratic development in recipient countries through dialogue rather than demands and conditionality (Crawford 2001: 57) following the principle of "assist rather than abandon" (Laakso 2002: 59). In practice, however, ideological affiliations were more influential, with socialist regimes receiving ca 80 percent of Sweden's foreign aid to Africa in the 1980s (Schraeder, Hook, and Taylor 1998). Yet the Social Democratic government did not roll back its predecessors' reforms, but rather continued increasing the commercialization of aid, moving toward the so-called OECD model, with a shift from grants to loans and from "recipient ownership" to conditionalities (Kärre and Svensson 1989; Brodin 2000: 30f).

When democracy promotion had its symbolic breakthrough in Swedish ODA policy toward the end of the decade, the Social Democratic government took the first step. Following the rapid fall of 
Communism, government launched development cooperation with Eastern Europe in 1990, with a focus on democratic consolidation, economic transformation, and environmental protection in the Baltic Sea region. This initiative followed international trends where major donors, including the US and the EU, redirected substantial resources from the third to the second world. Yet except for the Conservatives, all opposition parties opposed this policy shift, as it compromised the 1 percent target and the principle of aiding the poorest people (Brodin 2000: 33), by transferring funds from the ordinary development aid budget - in effect, as a Centre party politician put it, forcing Africa to foot the bill. A push for change also came from Nordic policy coordination: In 1989, a joint Nordic agreement declared democracy promotion as one of the primary aims of Nordic development cooperation and in 1990, the Nordic ministers of development cooperation met in Norway to issue a declaration that insisted on free elections and questioned single-party systems, especially in Africa (Crawford 2001: 57; Laakso 2002: 57, 60): "The connection between democracy, human rights and sustainable development has become more and more evident. ... open democratic systems and respect for human rights give impetus to efforts to achieve development, economic efficiency and equitable distribution" (Molde Declaration, cited in Crawford 2001: 57).

After the 1991 elections, the new centre-right coalition launched a major reorientation of development aid policy toward "a considerably stronger support for democracy and market economy" (Riksdagen 1991). Minister of development aid Alf Svensson (Christian Democrat) stated democracy and human rights as not only ends in themselves, but also preconditions for development (Crawford 2001). Expecting recipient countries to pursue policies that actually ensured respect for human rights and progress toward democracy and market economy also required stricter control and evaluation (Utrikesdepartementet 1993), while the economic crisis prompted budget cuts and organizational reforms in development aid. The new policy included an increased conditionality approach, a shift away from country-programming toward individual projects, a greater involvement of civil society both in Sweden and in recipient countries, and reduced aid to single-party regimes. Government cut aid to Vietnam, whose involvement in Kampuchea had already prompted discussions about decreasing aid in the late 1980s (Kärre and Svensson 1989: 256), terminated development cooperation with Cuba (Brodin 2000: 33f; Crawford 2001: 58), and continued supporting the transitioning states in Central and Eastern Europe. In 
1993, the official doctrine's goal of promoting democratic development was revised to also include "respect for human rights" (Laakso 2002: 60) and SIDA presented a strategy for democracy and human rights assistance. Democracy promotion prompted a range of new strategies and instruments, such as training for journalists, police forces and lawyers, support to NGOs, strengthening legislatures, combating corruption, and supporting elections, voter education, and election monitoring (Brodin 2000: 84). In short, the focus had shifted toward a model of liberal democracy and the rule of law as valuable not only in their own right, but also as important preconditions for development in poor and rich nations alike (Crawford 2001).

While in opposition, the Social Democrats charged the government with an impoverished understanding of democratization, lacking the insight that democratic institutions presuppose a democratic culture that only evolves over decades and centuries (Riksdagen 1992), but when they returned to power in 1994, they continued the predecessor's emphasis on democracy promotion in development aid. In 1995, the government founded the Institute for Democracy and Electoral Assistance (IDEA), an international organization seated in Stockholm devoted to furthering democracy across the world (Brodin 2000: 85). It also initiated a system (proposed by the previous government) of democracy support through party-affiliated organizations, which aimed to contribute to the development of pluralistic party systems and democratic societies in development countries and in Central and Eastern Europe, and carried through a reform pooling all public development aid agencies under SIDA's roof. ${ }^{3}$ By entering the European Union in 1995, Sweden also increasingly needed to coordinate its foreign policies with the $\mathrm{EU}$, which had a stronger emphasis on conditionality in its development policy, for instance mandating human rights clauses in all EU treaties with third countries (Laakso 2002: 60), but Sweden also found ways to take a leading role among like-minded states in EU development policies (Elgström and Delputte 2016). On the other hand, government also received massive criticism for reestablishing development cooperation with Cuba in 1995.

While the increasing emphasis on democracy and human rights implied that Swedish ODA increasingly adopted a conventional liberal

3 The acronym SIDA was kept, now spelled out as the Swedish International Development Cooperation Agency. 
model of electoral democracy and the rule of law, it also created new opportunities for combining these ideals with supposedly uniquely Swedish values and traditions. For instance, a 1998 government communication cites Swedish values and experiences as steering principles for democracy promotion efforts:

\begin{abstract}
It is those values we in Sweden associate with democracy that we want to promote in other countries too. Experiences from Swedish practice is a natural frame of reference when Sweden enters dialogues with representatives of other countries and cultures ... A characteristic of Swedish democracy has been the emphasis on political solutions based on consensus, a high degree of organization and participation by popular movements, as well as a strong pursuit of equality. (Utrikesdepartementet 1998)
\end{abstract}

Thus, while the turn to democracy promotion represented a major shift in Swedish ODA priorities, government officials could also frame it as policy continuity, by linking back to the idea of Sweden providing an egalitarian, participatory model for societal reform developing countries ought to emulate. Furthermore, the government also paraphrased the founding era's notion of democratization as a long-term goal and the difficulties of developing the institutional and cultural preconditions for a viable democracy: "[T]he transition to democracy often comes gradually. A first election can take a couple of years to prepare. Building democratic institutions can take decades, developing a democratic culture can take generations. All democratic forces must have reasonable expectations and show patience" (Utrikesdepartementet 1998: 7f).

In sum, the 1980s and 1990s entailed that democracy promotion was elevated from irrelevance to a central goal of Swedish development aid policy, due to the norm entrepreneurship of the Conservative party and facilitated by geopolitical upheavals and the emergence of international norms of democracy and aid conditionality in the 1980s. The period also substituted the previous wide notion of popular participation tolerant of single-party regimes with a distinctly liberal notion of electoral, multiparty democracy, and respect for human rights and the rule of law, although one key bone of contention concerned how to get there, with the Social Democrats emphasizing democratization as a long-term, gradual process whose societal preconditions could take decades to develop. Yet even as Sweden changed course and followed an international trend, policymakers could still find ways of justifying a unique role for Sweden in exporting its homegrown notions of democracy as a model for the developing world. 


\subsection{Agents of Change in Shrinking Spaces}

After the optimism of the 1990s, international development aid faced a new set of challenges after the turn of the millennium (Odén and Wohlgemuth 2010; Odén 2017): In 2000, the United Nations adopted its eight Millennium Development Goals, which focused on poverty reduction and conspicuously excluded democracy. Realizing that the great variety of donor aid programs were causing problems for recipient countries, the OECD sought to achieve greater coordination and harmonization of donor development aid policies, a process that resulted in the 2005 Paris Declaration on Aid Effectiveness. Meanwhile, following the terrorist attacks in the United States in 2001, the war on terror led to the increasing securitization of foreign aid. Afghanistan and Iraq demonstrated the futility of exporting electoral democracy to collapsed states, while the hopes of democratic transformation after the Arab Spring in 2011 were quickly crushed. The rise of China entailed that Western donors increasingly faced a new rival in developing countries (one that never raised any demands for democracy and human rights) and some former recipient countries also became development aid donors. While a billion people were alleviated out of extreme poverty, migrant remittances to developing countries started outdoing global ODA flows and proved more stable than foreign direct investments, not least during the 2008 financial crisis that had complicating repercussions for donor and recipient countries alike. Finally, stalled processes of democratization and rising authoritarian populism in many countries prompted challenges to the liberal multilateral world order, increasingly making the 1990s look like a parenthetical phase in world politics.

This backdrop set the external terms for reforms to Swedish ODA policy. In the early 2000s, a broad consultation process with civil society and state agencies resulted in a new overarching bill - Policy for Global Development (Politik för global utveckling, PGU) - setting priorities for development cooperation (Utrikesdepartementet 2003). The new policy entailed a major revision of Swedish ODA goals. Originally laid down in 1962, systematized in 1978 and revised incrementally with the addition of economic independence (1968), sustainable resource management (1987), and gender equality (1995), six goals, all supposedly equally important, governed Swedish ODA policy. Following OECD Development Assistance Committee (DAC) review recommendations on increasing focus, coherence, and priority among the numerous goals (Mikaelsson 2008: 175), the new policy stated only one goal for Swedish ODA policy: To reduce 
poverty. Yet ODA would also be guided by a poor persons perspective and a rights perspective, and under these general principles, the bill listed the six former goals as "directions" - and also added two new "directions": conflict management and human security, and global public goods. The implementation of this policy also entailed a greater emphasis on evaluation, accountability, transparency, and quality control. However, despite these efforts to provide coherence and coordination for Swedish ODA policy, the OECD-DAC would continue to express concern over the fuzziness of Swedish aid policy (Mikaelsson 2008: 176f), as trying to do too many things in too many recipient countries.

The rights perspective in the new policy rested on the normative foundation of the equal dignity and rights of all human beings, and described democracy and human rights as instrumental for securing those values. Hence, on this view, the right of all persons to influence and participate in the governance of their society is accomplished through democracy "in the principles of one person, one vote and equality before the law" (Mikaelsson 2008, citing the bill). Beyond democratic participation, the rights perspective also entailed a new emphasis on countering discrimination as an obstacle to development. The rights and the poor persons perspectives further entailed a normative shift: Where traditionally Sweden had earlier identified the recipients of its aid as "peoples," which mostly meant states, cooperation would now focus on empowering individuals as active participants in the process of development. Pointing to Swedish historical experiences, the bill also stressed the importance of having democratic mechanisms for peaceful management of conflicts and antagonisms to create a will to compromise among different interest groups (Utrikesdepartementet 2003: 24). "Even if complete models cannot be exported," the bill noted, Swedish modern history shows how central social security, the welfare state, and close collaboration between the social partners are for social stability - experiences that "are important in global perspective too" and motivate a "special Swedish engagement" (Utrikesdepartementet 2003: 29, 56).

A new centre-right government coalition gaining power in the 2006 elections raised the level of political contestation over development aid policy and again brought democracy promotion to the forefront. The government shift provided an opportunity to debate fundamental ideas in ODA doctrine, such as the 1 percent target, which made the Swedish ODA budget fluctuate with domestic growth, and whether development aid was actually promoting development at all. The new Conservative 
minister for development Gunilla Carlsson launched an ambitious reform agenda, seeking to reduce the number of key recipient countries from 70 to 33, to scale down Sweden's participation in multilateral development organs and to rationalize the Swedish aid bureaucracy, with a greater emphasis on aid efficiency and results-based management. While the minister failed to convince coalition partners to abolish general budget support altogether, it was conditioned on stricter democracy and anti-corruption criteria (Larsson 2018). Furthermore, the government also initiated a major overhaul of Swedish democracy assistance (Utrikesdepartementet 2008), focused on promoting civil and political rights; strengthening democratic and rule-of-law institutions, including elections, party systems, and judiciaries; and supporting the "agents of change," chiefly pro-democratization groups in civil society. The minister declared her ambition "to fill the democracy aim with new content. Dictators [... s] should fear Swedish aid" (Orrenius 2008), and democracy assistance doubled in a ten-year period, growing to the largest sector of bilateral aid.

In 2014, seeking to clarify the hierarchy of objectives in Swedish ODA policy, government introduced a new "aid policy platform," which proposed a new overarching goal: "improved living conditions for people who live in poverty and oppression" (Utrikesdepartementet 2014). Hence, political oppression was put on a par with poverty in the official doctrine, thus codifying the increasing focus on democracy and human rights, yet the proliferation of goals continued, as the policy also included six broad and diverse sub-objectives, among them "strengthened democracy and gender equality, greater respect for human rights and freedom from oppression" (Utrikesdepartementet 2014). Echoing previous claims to a unique role for Sweden, Carlsson's successor Hillevi Engström maintained that unlike new donors that hardly care for human rights and democracy, "Swedish aid has a special added value in the area of democracy and human rights. We have extensive experience of working with these issues. We live in a society where democracy and human rights are seen as self-evident and are deeply rooted" (Engström 2013). Yet Sweden's mission was now based on a causal belief where liberal institutions were seen as prerequisites for socioeconomic development, rather than the other way around: "Respect for civil and political rights and the rule of law are decisive for building democracy and reducing poverty and oppression."

When a Social Democrat and Green Party coalition took office in 2014, a key concern was how to promote democracy in times of 
democratic backsliding and shrinking spaces for participation, thus continuing the previous government's focus on activists in civil society. Government ambitiously declared that "democracy, human rights and ... the rule of law would permeate Swedish foreign policy in its entirety" (Utrikesdepartementet 2016) and that Sweden would pursue a feminist foreign policy, which translated into an even stronger emphasis on gender equality in development aid, including a more equitable distribution of political power, influence, and resources. Dusting off the 2003 PGU, the new government pledged to align its policies, including ODA, to Agenda 2030 and the Sustainable Development Goals (which however lacked an explicit democracy goal).

While the government claimed that Sweden's international credibility depended on consistently pursuing the ambitious agenda (Utrikesdepartementet 2016), critics argued that government compromised the democratization aims through budget cuts and reallocations, partly due to rising indonor costs for refugee reception, and foreign policy objectives, such as Sweden's campaign to get elected to the UN Security Council. Government also continued downsizing general budget support due to its politically sensitive nature. Moreover, following a pattern from previous government shifts, government also resumed bilateral aid to Cuba, partly on occasion of the EU's negotiating a bilateral trade agreement.

In sum, while policymakers in the post-millennium period were initially struggling to make sense of the multiplying aims of Swedish development aid, the Conservative-led government aspired to make democracy and human rights its guiding principles. Occurring at a time when other donors largely regarded democracy export on the transition paradigm a failed project (Carothers 2002), Sweden seemingly resisted an international trend. On the other hand, the more dominant, multifaceted and all-sector permeating the principles of democracy, human rights, and rule of law became, the more malleable they also became in their practical operationalization. Sweden thus also reflected an international trend where broader ideas about participatory self-governance came to pervade most fields of development aid, such as state-building, conflict management, and climate change (Schmidt 2015).

\subsection{Conclusion}

This chapter has analyzed how democracy promotion became a central aim of Swedish development aid policy. Today, support for democracy, 
civil society, human rights, and good governance comprises the largest single budget post in Swedish development cooperation, and is being touted by leading policymakers as a special role for Sweden - a national brand, if you like. Positioning my argument in contradistinction to existing culturalist accounts that would assume the exceptional role of Sweden to result from deep-seated values prevalent in domestic society, I argued that the central role of democracy assistance in Sweden's development aid policy rather results from political contestation in domestic politics partly influenced by international events and conjectures, as political parties and other groups mobilize different ideas with a view to determine public policy, in aid as in any other policy field.

The first thing to note is that if seeking to promote democracy through development aid were just a reflection of values predominant in Swedish culture, we would expect it to stay fairly constant over time and largely unaffected by international conjectures. Yet in fact this analysis has revealed that reflecting international developments (arguably even with some lag), democracy promotion remained in practice a nonissue in Swedish development aid until it had its breakthrough around 1990. From its inception in 1962, Swedish development aid doctrine rested on a notion of democracy so wide it could allow for single-party regimes, a theory of development that prioritized resource growth, social equalization, and political independence, and a conviction against imposing allegedly Western values or donor conditionalities on Third World countries. In its focus on economic growth and tolerance of authoritarian regimes, Swedish aid was not so different from other donors at the time. When the international aid discourse gained a focus on democracy, human rights, good governance, and conditionalities in the 1980s, while the third wave of democratization and the demise of the super-power conflict raised a new set of challenges, Conservative norm entrepreneurship contributed to making democracy promotion a key priority in Swedish development aid, leading to a range of new strategies and instruments. Democracy and human rights were more extensively codified in doctrine by the early 2000s, and the 2006 centre-right government initiated a major reform of development aid, expanding democracy assistance to the largest sector in SIDA's budget. Hence, while official doctrine and its interpreters sometimes claim continuity in Swedish ODA policy goals (e.g. Wohlgemuth 2012), democracy assistance rather represents a remarkable volte face, influenced by international trends and domestic political contestation. 
Second, as these shifts also reveal, there has at times been considerable politicization of democracy as an aim guiding development aid policy. Swedish development aid policy is often described as rooted in a broad consensus in both elite and popular opinion. Yet looking back at six decades of development policy evolution, policy aims and strategies rather seem formulated through compromises that result from a contentious process where the relative strength and preferences of political parties have shaped the outcome. Moreover, the democracy-promotion aim has evolved in a strikingly dialectic fashion, where doctrines formulated by Social Democrat governments are challenged by the nonsocialist opposition parties, whose policy innovations once they are in government form the basis of a new partial consensus when the Social Democrats resume power. For instance, the centre-right coalitions in the 1990s and the 2000s-2010s made the promotion of democracy, human rights, and the rule of law leading principles of Swedish development aid, while their Social Democratic successors largely accepted both the policy aims and the resulting strategies.

Third, beyond such partisan politics, however, it is intriguing to see the use of development aid as a nation branding strategy, where democracy and human rights have successively come to be a defining feature. One aspect of continuity is the idea that Sweden, by virtue of its historical experiences and its special relationship to developing countries, has an important role to play in world affairs. While the notions of democratization and democracy implicit in Swedish ODA have changed drastically since the Cold War era, the idea that Sweden has a mission in providing a model to the world is strangely resilient. Moreover, Sweden's ODA generosity paid off by boosting its standing in international affairs: By reaching and exceeding the UN 0.7 percent aid target, Sweden gained an authoritative status to criticize other countries and a wider hearing on its point of view on international issues (Ekengren and Götz 2013: 30). The expansion of democracy and human rights promotion may have contributed to enhancing that national branding effort, in an era when aid quantity alone no longer served as a key marker of moral distinction. $^{4}$

4 Tellingly, Sweden's public diplomacy agency the Swedish Institute now also funds development aid projects that promote democracy. 


\section{References}

Axell, I. (1989). SIDA's View on the Relationship between Development Assistance and Human Rights. In L. A. Rehof \& C. Gulmann, eds., Human Rights in Domestic Law and Development Assistance Policies of the Nordic Countries. Copenhagen: Martinus Nijhoff Publishers, pp. 31-34.

Bergman Rosamond, A. (2007). Co-constitution of Domestic and International Welfare Obligations: The Case of Sweden's Social Democratically Inspired Internationalism. Cooperation and Conflict, 42(1), 73-99.

(2015). Swedish Internationalism and Development Aid. The Oxford Handbook of Swedish Politics. In J. Pierre, ed., The Oxford Handbook of Swedish Politics. New York: Oxford University Press, pp. 462-478.

Berman, S. (2013). Ideational Theorizing in the Social Sciences since "Policy Paradigms, Social Learning, and the State." Governance, 26(2), 217-237.

Bjereld, U. \& Demker, M. (1995). Utrikespolitiken som slagfält: De svenska partierna och utrikesfrågorna. Stockholm: Nerenius \& Santérus.

Boréus, K. (1994). Högervåg: Nyliberalismen och kampen om språket i svensk debatt 1969-1989. Stockholm: Tiden.

Brodin, A. (1992). Bistånd och demokrati: Demokratimålet $i$ den svenska biståndspolitiska doktrinen 1962-1991. En analys av uttalanden i riksdagsdebatten. Licentiatuppsats, Göteborg: Göteborgs universitet.

Brodin, A. (2000). Getting Politics Right: Democracy Promotion as a New Conflict Issue in Foreign Aid Policy. Gothenburg: University of Gothenburg.

Brysk, A. (2009). Global Good Samaritans: Human Rights as Foreign Policy. Oxford: Oxford University Press.

Carothers, T. (2002). The End of the Transition Paradigm. Journal of Democracy, 13(1), 5-21.

Crawford, G. (2000). Promoting Democratic Governance in the South. European Journal of Development Research, 12(1), 23.

(2001). Foreign Aid and Political Reform: A Comparative Analysis of Democracy Assistance and Political Conditionality. Basingstoke: Palgrave.

Dahl, A. S. (2005). Sweden: Once a Moral Superpower, Always a Moral Superpower? International Journal, 61(4), 895-908.

Ekengren, A. M. \& Götz, N. (2013). The One Per Cent Country: Sweden's Internalisation of the Aid Norm. In T. B. Olesen, H. Pharo, \& K. Paaskesen, eds., Saints and Sinners: Official Development Aid and Its Dynamics in a Historical and Comparative Perspective. Bergen: Fagbokforlaget, pp. 21-49.

Elgström, O. \& Delputte, S. (2016). An End to Nordic Exceptionalism? Europeanisation and Nordic Development Policies. European Politics and Society, 17(1), 28-41.

Engström, H. (2013). Demokrati och bistånd - svensk politik. Speech, Lund. December 10. 
Holmberg, S. L. (1989). Welfare Abroad: Swedish Development Assistance. In B. Sundelius, ed., The Committed Neutral: Sweden's Foreign Policy. Boulder: Westview Press, pp. 123-166.

Hook, S. W. (1995). National Interest and Foreign Aid. Boulder: L. Rienner Publishers.

Huber, D. (2015). Democracy Promotion and Foreign Policy: Identity and Interests in US, EU and Non-Western Democracies. London: Palgrave Macmillan.

Kärre, B. \& Svensson, B. (1989). The Determinants of Swedish Aid Policy. In Western Middle Powers and Global Poverty: The Determinants of Aid Policies of Canade, Denmark, the Netherlands, Norway and Sweden. Uppsala: The Scandinavian Institute of African Studies, pp. 231-274.

Kuisma, M. (2007). Social Democratic Internationalism and the Welfare State after the "Golden Age." Cooperation and Conflict, 42(1), 9-26.

Laakso, L. (2002). Promoting a Special Brand of Democracy: Denmark, Finland, Norway, and Sweden. In P. J. Schraeder, ed., Exporting Democracy: Rhetoric vs. Reality. London: Lynne Rienner, pp. 55-71.

Langford, M. \& Schaffer, J. K. (2015). The Nordic Human Rights Paradox: Moving Beyond Exceptionalism. University of Oslo Faculty of Law Research Paper No. 2013-25.

Larsson, K. A. (2018). The Rise and Fall of Budget Support in Swedish Development Cooperation. EBA Working Paper. Expert Group for Aid Studies.

Lawler, P. (1997). Scandinavian Exceptionalism and European Union. JCMS: Journal of Common Market Studies, 35(4), 565-594.

(2005). The Good State: In Praise of “Classical” Internationalism. Review of International Studies, 31(3), 427-449.

Lödén, H. (1999). "För säkerhets skull”: Ideologi och säkerhet i svensk aktiv utrikespolitik 1950-1975. Stockholm: Nerenius \& Santérus.

Mikaelsson, R. (2008). Promoting Democracy: Sweden and the Democratisation Process in Macedonia. Linköping: Linköping University.

Odén, B. (2017). Sverige och internationellt utvecklingssamarbete. In D. Brommesson \& A. M. Ekengren, eds., Sverige i Världen. Malmö: Gleerups, pp. 163-186.

Odén, B. \& Wohlgemuth, L. (2010). Svensk biståndspolitik $i$ ett internationellt perspektiv. Göteborg: School of Global Studies, University of Gothenburg.

Orrenius, A. (2008). Carlsson vill ha med riksdagen i biståndet. Riksdag \& Departement, 1 September 2008.

Riksdagen (1991). Protokoll 1991/92:6.

(1992). Protokoll 1991/92:98.

Rothstein, B. (1998). Just Institutions Matter: The Moral and Political Logic of the Universal Welfare State. Cambridge: Cambridge University Press. 
Schaffer, J. (2017). Mellan ambivalens och aktivism: Norden och internationella mänskliga rättigheter. Retford, 40(1), 55-72.

(2020). The Self-Exempting Activist: Sweden and the International Human Rights Regime. Nordic Journal of Human Rights, 38(1), 40-60.

Schmidt, J. (2015). Rethinking Democracy Promotion in International Relations: The Rise of the Social. Abingdon \& New York: Routledge.

Schmidt, V. A. (2008). Discursive Institutionalism: The Explanatory Power of Ideas and Discourse. Annual Review of Political Science, 11(1), 303-326.

Schraeder, P. J., Hook, S. W., \& Taylor, B. (1998). Clarifying the Foreign Aid Puzzle: A Comparison of American, Japanese, French, and Swedish Aid Flows. World Politics, 50(2), 294-323.

Utrikesdepartementet (1962a). Aspekter på utvecklingsbiståndet: Promemorior överlämnade till beredningen för internationella biståndsfrågor. SOU 1962:12. Stockholm.

(1962b). Kungl. Maj:ts proposition till Riksdagen angående svenskt utvecklingsbistånd. Prop. 1962:100.

(1968). Kungl. Maj:ts proposition till Riksdagen angående långtidsplan för det statliga utvecklingsbiståndet $m$. m. Prop. 1968:101.

(1977). Sveriges samarbete med U-länderna: Huvudbetänkande av biståndspolitiska utredningen. SOU 1977:13.

(1978). Om riktlinjer för intemationellt utvecklingssamarbete. Prop. 1977/78:135.

(1993). Om styrnings- och samarbetsformer i biståndet. Prop. 1992/93:244.

(1998). Demokrati och mänskliga rättigheter $i$ Sveriges utvecklingssamarbete. Skr. 1997/98:76.

(2003). Gemensamt ansvar: Sveriges politik för global utveckling. Prop. 2002/03:12.

(2008). Frihet från förtryck - Skrivelse om Sveriges demokratibistånd. Skr. 2008/09:11.

(2014). Biståndspolitisk plattform. Skr. 2013/14:131.

(2016). Mänskliga rättigheter, demokrati och rättsstatens principer i svensk utrikespolitik. Skr. 2016/17:62

Witoszek, N. \& Midttun, A., eds. (2018). Sustainable Modernity: The Nordic Model and Beyond. Abingdon \& New York: Routledge.

Wohlgemuth, L. (2012). Svenskt utvecklingssamarbete 50 år. Perspectives 23. School of Global Studies, University of Gothenburg.

Youngs, R. (2008). What Has Europe Been Doing? Journal of Democracy, 19(2), $160-169$. 